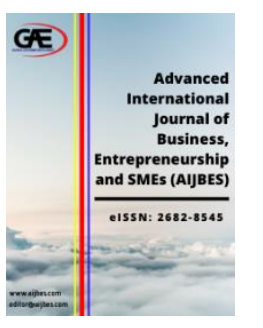

\author{
ADVANCED INTERNATIONAL JOURNAL OF \\ BUSINESS, ENTREPRENEURSHIP AND SMES \\ (AIJBES) \\ www.aijbes.com
}

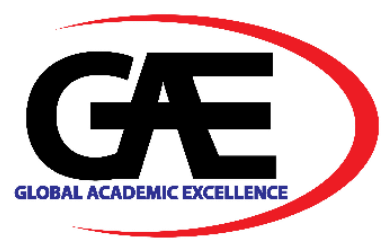

\title{
PROPOSED BUSINESS STRATEGY FOR SMALL ARCHITECTURE FIRM IN TANGERANG: CASE STUDY TOP HOUSE
}

\author{
Kartika Devi Ariyanti $^{1 *}$, Alibasjah Inggriantara ${ }^{2}$ \\ 1 School of Business and Management, Institut Teknologi Bandung (ITB), Indonesia \\ Email: kartika_ariyanti@sbm-itb.ac.id \\ 2 School of Business and Management, Institut Teknologi Bandung (ITB), Indonesia \\ Email: alibasjah.i@gmail.com \\ * Corresponding Author
}

\begin{abstract}
Article Info:
Article history:

Received date: 16.03 .2021

Revised date: 24.03 .2021

Accepted date: 10.12 .2021

Published date: 12.12 .2021

\section{To cite this document:}

Ariyanti, K. D., \& Inggriantara, A. (2021). Proposed Business Strategy For Small Architecture Firm In Tangerang: Case Study Top House. Advanced International Journal of Business, Entrepreneurship and SMEs, 3 (10), 49-68.
\end{abstract}

DOI: $10.35631 /$ AIJBES.310005.

This work is licensed under $\underline{\mathrm{CC} B Y} 4.0$

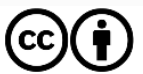

\begin{abstract}
Top House is a small architecture firm located in South Tangerang that focuses on design consultants for low and medium-rise buildings. The preliminary study has been conducted by interviewing the firm's owner who also acts as the principal architect, to identify company problems. The results showed that the company revenue and net profit decreased significantly by about $20 \%$ from 2017 to 2019 and $75 \%$ from 2016 to 2019. Moreover, the consultancy service orders became small and decreased from 2015-2019. The decreased revenue and net profit were caused by a poor company and incomprehensive management system. To solve the problem using the external and internal environmental analysis. The external environmental analysis used the PESTEL, Porter Five's Forces, and competitor analysis. Meanwhile, the internal environmental analysis used the VRIO framework, value chain analysis, and existing Business Model Canvas (BMC). Afterward, the data were summarized in the SWOT table for strategy formulation. It consisted of IE matrix and TOWS matrix as company level strategy and functional level strategy, then the new proposed Business Model Canvas (BMC). Based on the analysis of IE Matrix, the current company classification position is in cluster five. This indicates that the company should implement a hold and maintain business strategy with two options, namely market penetration and product development. Furthermore, pros and cons analysis is used to obtain the best strategy from these options. The company should implement a product development strategy by improving the existing product quality, namely green architectural requirements in the design concept and utilizing BIM technology. The TOWS matrix resulted in 11 functional strategies applied in the marketing, human resources, operations, and financial field.
\end{abstract}




\section{Introduction}

Tangerang is an area with a potentially large market for architecture business. Based on BPS data, in September 2019, DKI Jakarta and Banten provinces were classified among the top ten average expenditures for housing, household facilities, various goods, and services. Tangerang area was the largest sales property compared to others in 2019 due to the increasing development. Further, it was close to DKI Jakarta as the center of national economic activity (Fauzian, 2019). This condition allowed the architectural firm business to experience growth despite the competition. However, the Covid-19 pandemic led to its decline, and demand for architecture firms shifted to landed house project typology (Archify, 2019 \& Lusida, 2020). This situation contributed to higher supply than demand, which is challenging. Therefore, the architecture firm should create a unique value product from the competitors to emerge the best.

Top House is a private company engaged in an architecture firm focus on low and mediumrise building projects with client B2C model. Furthermore, it has various types of projects located in the Bumi Serpong Damai (BSD) and Jakarta area, specifically residential houses, offices, warehouses, shops, and apartment units. This firm was established in early 2015 with its official office in Bumi Serpong Damai (BSD), Tangerang. It aimed to produce a low and medium-rise building with a good reputation, sustainable, and competitive advantages in the Jabodetabek area.

Since its establishment in 2015, the owner expected growth and increased revenue and profit from architectural consultation services. In early 2015, the company created a vision and mission, though it did not take concrete steps to achieve or realize its targets. In this regard, there were no written business strategies/ plans, formal company targets, and proper management system. The management was established conventionally with no periodic evaluation. This condition was manifested in performance parameters, including the significant revenue and net profit decrease with 20\% from 2017 to 2019 and 75\% from 2016 to 2019, respectively. Furthermore, the service orders for consultancy became small and decreased from 2015-2019. Currently, this company is unable to compete with its opponents and realize its vision and mission. Therefore, it should establish fundamental changes in strategizing business for consultancy architects, gain revenue $\&$ large market share, and increase profit.

\section{Literature Review}

\section{Strategic Management}

Strategic management is defined as the art and science of formulating, implementing, and evaluating cross-functional decisions that enable an organization to achieve its objectives. Based on this definition, strategic management focuses on integration, marketing, finance/accounting, production/operations, research and development, and information systems to achieve organizational success (Fred R. David, 2011). According to Wheelen \& Hunger (2012), Strategic management is a set of managerial decisions and actions that determines the longrun performance of a corporation. Similarly, Fred R. David (2011: 38) stated that its process consists of three stages, specifically, strategy formulation, strategy implementation, and strategy evaluation. Wheelen \& Hunger (2012) showed external and internal environmental scanning, strategy 
Volume 3 Issue 10 (December 2021) PP. 49-68 DOI 10.35631/AIJBES.310005

formulation, strategy implementation, evaluation, and control. Further, Rothaermel (2017) defined strategic management as an integrative management field that combines analysis, formulation, and implementation in the quest for competitive advantage.

There are three elements to produce a good strategy (Rothaermel, 2017), including:

1. Diagnosis of the competitive challenge is accomplished through analysis of the firm's external and internal environments.

2. A guiding policy addressing the competitive challenge is achieved through strategy formulation, leading to the firm's corporation, business, and functional strategies.

3. A set of coherent actions to implement the firm's guiding policy is attained through strategy implementation.

\section{Strategy Formulation}

Strategy-formulation techniques are integrated into a three-stage decision-making framework. The tools presented here apply to all sizes and types of organizations and help strategists identify, evaluate, and select strategies. The three stages include:

1. The input stage summarizes the basic input information needed to formulate strategies. This study uses a formulation framework consisting of the EFE and IFE Matrix. An External Factor Evaluation (EFE) allows strategists to summarize and evaluate economic, social, cultural, demographic, environmental, political, governmental, legal, technological, and competitive information. The Internal Factor Evaluation (IFE) summarizes and evaluates the major strengths and weaknesses in the business functional areas and provides a basis for identifying and evaluating relationships among these areas.

2. The matching stage focuses on generating feasible alternative strategies by aligning key external and internal factors. It uses IE Matrix techniques based on two dimensions specifically, the IFE and EFE total weighted scores on the $\mathrm{x}$ - and y-axis, respectively. Based on this, recall that each division of an organization should construct an IFE and EFE Matrix for its part. The total weighted scores derived from the divisions allow the corporate-level IE Matrix (Fred R. David, 2011).

3. The decision stage use pros and cons as an alternative strategy. According to Franklin, the best way to reach an optimal solution in a tough decision is use pros and cons analysis, which validates his system for a single decision (Charyk, 2017).

The TOWS matrix illustrates how the external opportunities and threats facing a particular corporation are matched with that company's internal strengths and weaknesses to result in four sets of possible strategic alternatives (Wheelen,2012).

\section{Product Development}

It is a strategy that increases sales by improving or modifying present products or services (Fred R. David, 2011).

\section{PESTEL Analysis}

It is a framework for evaluating the impact of the firm's external environmental factors affecting its potential to gain and sustain a competitive advantage. These factors create both opportunities and threats for the company. PESTEL stands for Political, Economic, Social, Technological, Environmental, and Legal factors (Rothaermel, 2017). 


\section{Porter's Five Forces Analysis}

This model is a framework that identifies five forces determining an industry's profit potential and shapes a firm's competitive strategy. It consists of a threat of entry, power of suppliers, power of buyers, threat of substitutes, and rivalry among existing competitors. A five forces analysis provides the basis for firm positioning to gain and sustain a competitive advantage (Rothaermel, 2017).

\section{Competitor Analysis}

This deals with identifying its competitors and evaluating strategies to determine their strengths and weaknesses relative to the own product or service (Kotler Armstrong: 2016). Therefore, it is needed for companies to have more detailed knowledge about competitors and also determine the right marketing strategy to fight competitors (Oman, 2015).

\section{VRIO Framework}

VRIO represents a framework addressing the resource attributes underpinning competitive advantage. A resource qualifying to form a basis of competitive advantage should be valuable $(\mathrm{V})$, rare $(\mathrm{R})$, costly to Imitate $(\mathrm{I})$, and organized to capture the value $(\mathrm{O})$ of the resource (Rothaermel, 2017).

\section{Value Chain Analysis}

This describes the internal activities that a firm engages in when transforming inputs into outputs. Each activity the firm performs along the horizontal chain adds incremental value. The framework of the value chain has two categories, including primary and support activities. In this regard, Primary activities ones contribute to the creation of value directly, whereas support activities consist of functions and tasks intended to anchor primary activities. (Rothaermel, 2017).

\section{Business Model Canvas}

This is a framework business template consisting of nine squares that are mutually exclusive related. These boxes contain the essential illustrating elements of how the organization creates value and benefit from its customers (Osterwalder \& Pigneur, 2010).

\section{SWOT Analysis}

It evaluates a firm's current situation and prospects by simultaneously considering internal and external factors. Therefore, it focuses on these factors affecting the firm's ability to gain and sustain a competitive advantage either positively or negatively (Rothaermel, 2017). According to Kotler, Keller (2009: 89), the overall evaluation of the strengths, weaknesses, opportunities, and threats is also called SWOT analysis. Rangkuti (2008:18) stated that this analysis is used to identify various factors systematically to formulate strategy. It is based on the logic that maximizes the strengths and opportunities and minimizes weaknesses and threats mutually.

\section{Conceptual Framework}

Conceptual framework is the path of a research to become meaningful, acceptable, and provide the best explanation of the natural phenomenon progression for study (Adom, 2018). Furthermore, it outlines the plans for research thesis. In general, the conceptual framework guides the researcher to ensure the study is relevant and is described as follows: 


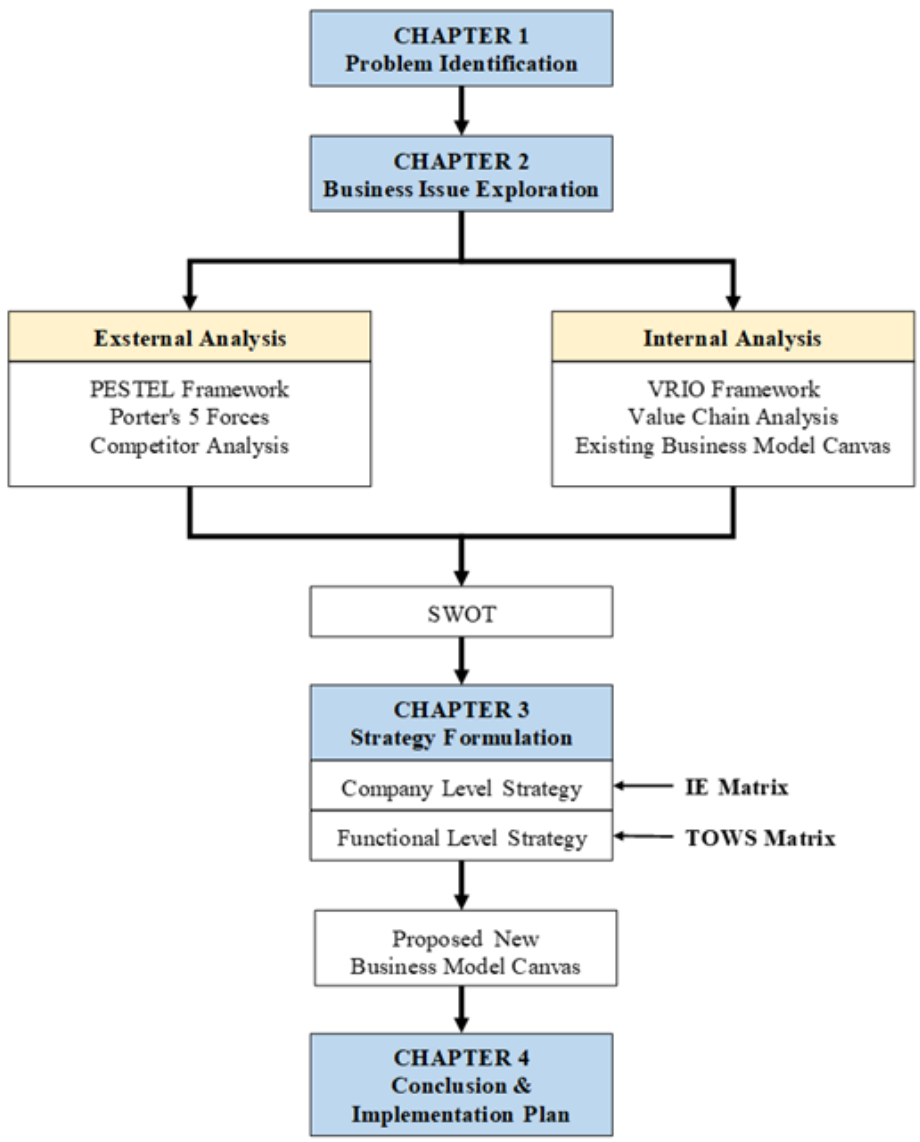

Figure 1. Conceptual Framework

Source: Author Analysis, 2020

\section{Research Methodology}

This study used a qualitative research method with data collected from the reasoning behind individuals, industry, and stakeholders (known as the 'why'). Specifically, it was conducted through open-ended, exploratory questions to seek a deep understanding of social phenomena within their natural setting (Utah University. 2019). Pure qualitative research relies on the collection of qualitative data. There are two categories method use to gather information, namely primary data and secondary data (Douglas, 2015). According to Mesly (2015), primary data is collected directly from the first person while secondary is from other research conducted by different people. Primary data in this study was collected directly from the internal organization Top House, the parties related, and the client as a customer through in-depth interviews, focus group discussion, and observations method. Qualitative interviews were conducted face-toface with participants, telephone, or engaged in the focus group with six to eight interviewees in each group (Creswell, 2018). Meanwhile, the secondary data was obtained through offline sources like books and online resources, including journals, reports, articles, websites, government publications, industry Associations.

The in-depth interview with the firm's owner who also acts as the principal architect, was performed since the study began by identifying the problem in the company. The interview results were used as the data for external analysis, consisted PESTEL, Porter Five's Forces, and competitor analysis. However, they were also used for internal analysis, consisted the VRIO framework, value chain analysis, and business model canvas. The internal analysis data is also 
strengthened by the results of interviews from clients, internal organizations and related parties. Furthermore, the group discussion with five architects within the organization aimed to determine results in the IE matrix as strategy formulation.

The study began by finding the problem with the architecture firm of Top House. Afterward, the business issue was explored by analyzing the environment's internal and external conditions. The external analysis methodology consisted PESTEL, five forces porter, and competitor analysis, while internal analysis methodology consisted VRIO framework, value chain analysis, and existing business model canvas. The results were then summarized in the SWOT table for the strategy formulation, which consisted of IE matrix as the firm's company level strategy and TOWS matrix as the firm's functional level strategy. The company level strategy will determine the business direction and achieve its objectives, whereas the functional level strategy will define the specific actions of the department. They also connect and support each other, followed by the proposed new business model canvas.

\section{Findings And Argument}

\section{PESTEL Analysis}

Table 1: The Results of PESTEL Analysis

\begin{tabular}{|c|c|c|}
\hline \multicolumn{3}{|l|}{ Factors } \\
\hline Political & National issue and global issue. & Threat \\
\hline Economical & $\begin{array}{l}\text { Indonesia's GDP 2020. (World Bank, } \\
\text { 2020) } \\
\text { The interest rate decreased in } 2019 \text { to } \\
\text { 2020. (Trading Economics, 2020) } \\
\text { - The inflation rate. (World Bank, 2020) }\end{array}$ & $\begin{array}{l}\text { This situation potentially } \\
\text { affects the decreasing } \\
\text { demand of the property and } \\
\text { architecture consultant } \\
\text { service. }\end{array}$ \\
\hline Social & $\begin{array}{l}\text { The population of Indonesia is ranked } \\
\text { position } 4 \text { in the world and has increased } \\
\text { annually with yearly growth under } 1 \% \text {. } \\
\text { (Worldometers, 2020) } \\
\text { - Jakarta and Banten are the top ten re- } \\
\text { gions with the most household consump- } \\
\text { tion in Indonesia. (Fauzian, } 2019 \& \text { } \\
\text { BPS, 2019) } \\
\text { Modern style is among the architectural } \\
\text { designs which are popular and long-last- } \\
\text { ing in the market. (Cendana, } 2015 \& \\
\text { Dekoruma, 2020). } \\
\text { The situation covid-19 changes the inter- } \\
\text { est in specific project typology of hous- } \\
\text { ing, education, hospital. (Archify, } 2020 \\
\text { \& Lusida, 2020) } \\
\text { The trend of the architectural style will } \\
\text { be included in the environment factor in } \\
\text { the future. (Newdecortrends, 2020 \& } \\
\text { Mazaya, 2020) }\end{array}$ & $\begin{array}{l}\text { Opportunity } \\
\text { This situation potentially } \\
\text { affects the increasing de- } \\
\text { mand of the property and } \\
\text { architecture consultant ser- } \\
\text { vice specifically for hous- } \\
\text { ing typology. }\end{array}$ \\
\hline
\end{tabular}




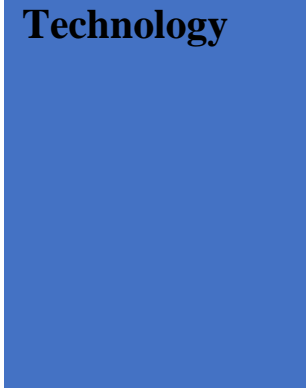

Environmental

Legal
- Technology and internet development are growing rapidly in Indonesia and are supported by the government. (HootSuite, 2020 \& Kemenperin, 2017)

- The phenomenon of the industrial era 4.0 is Innovation technology for architecture. (Hanegraaf, 2017., Autodesk, 2020., Pawitro, 2020 \& IAI, 2020).

The global warming issue (NOAA, 2019) and green architecture (Yeang, 2000 \& Constructor, 2014,).

Architect Certificate requirement, Indonesian Architects Association (IAI). (IAI, 2020).
Opportunity

The technology can trigger the business process architecture service faster, effective, and efficient with high-quality product services.

\section{Opportunity}

Demand for green buildings will increase.

Opportunity

Assurance architect capability and expertise.

Source: Author Analysis, 2020

PESTEL Analysis is a framework used to identify the macro-environment in the company. Six factors influence the small architecture firm, consisted political, economic, social, technological, environmental, and legal. The first step is to identify variables that affect the company and assess them to find out how much influence and impact it has, then categorized them whether the category is an opportunity or a threat. Technological, environmental, and social factors are categorized as opportunities and they have a strong influence and impact, while politic, economic factors are categorized as threats. This analysis will be explained further in the SWOT analysis section.

\section{Porter's Five Forces Analysis}

Table 2: Top House Porter Five Forces Analysis

\begin{tabular}{|l|c|}
\hline \multicolumn{1}{|c|}{ External Forces of the Business } & Results \\
\hline The threat of new entrants & High \\
\hline Bargaining power of suppliers & Medium \\
\hline Bargaining of buyers & High \\
\hline The threat of substitutes products or services & Low \\
\hline Rivalry among existing competitors & High \\
\hline
\end{tabular}

Source: Author Analysis, 2020

Porter's Five Forces is a framework for analyzing a company's competitive environment. The data collected through interviews with the top management level were analyzed. Based on this analysis, the threat of the new entrant, bargaining of the buyer, and rivalry among existing competitors are in the high forces category. This input is a threat that makes the competition among small architecture businesses difficult. Furthermore, several competitors and new entrants offer to lower the price to obtain orders, hence, creating a price war among them. However, the Bargaining power of suppliers and threat of substitutes products or services are categorized below high and have less impact. This analysis will be explained further in the SWOT analysis section.

\section{Competitor Analysis}


Volume 3 Issue 10 (December 2021) PP. 49-68 DOI 10.35631/AIJBES.310005

This is the process of identifying the competitors. The data collected through interviews, observation, and check website. Top House has three competitors with similar products, business scope, market area, segment market and location proximity, namely Formative, Soni Budiono Architect, and Studio Air Putih. From the analysis, the architecture firms have the same products with a similar price. In general, Top House has the lowest price than others although it is still under other competitor reputation, especially with Studio Air Putih that has many awards. Furthermore, its marketing is unaggressive than other competitors, only using word of mouth with no distribution channel. This analysis will be explained further in the SWOT analysis section.

\section{VRIO Framework}

Table 3: VRIO Framework of Top House

\begin{tabular}{|c|c|c|c|c|c|}
\hline Resource & Valuable & Rare & $\begin{array}{l}\text { Costly to } \\
\text { Imitate }\end{array}$ & $\begin{array}{l}\text { Organized } \\
\text { to capture } \\
\text { value } \\
\end{array}$ & $\begin{array}{l}\text { Competitive } \\
\text { Advantage }\end{array}$ \\
\hline \multicolumn{6}{|l|}{ Tangible } \\
\hline Financial capability & Yes & No & No & No & $\begin{array}{l}\text { Competitive Par- } \\
\text { ity }\end{array}$ \\
\hline Strategic Office & Yes & No & No & Yes & $\begin{array}{c}\text { Temporary } \\
\text { competitive } \\
\text { advantage }\end{array}$ \\
\hline $\begin{array}{l}\text { large storage for ma- } \\
\text { terials sample }\end{array}$ & Yes & No & No & Yes & $\begin{array}{l}\text { Temporary } \\
\text { competitive } \\
\text { advantage }\end{array}$ \\
\hline $\begin{array}{l}\text { High specification } \\
\text { Hardware for de- } \\
\text { signer }\end{array}$ & Yes & No & No & Yes & $\begin{array}{l}\text { Temporary } \\
\text { competitive } \\
\text { advantage }\end{array}$ \\
\hline Software for designer & Yes & No & No & Yes & $\begin{array}{l}\text { Temporary } \\
\text { competitive } \\
\text { advantage }\end{array}$ \\
\hline Office supplies & Yes & No & No & No & $\begin{array}{l}\text { Competitive Par- } \\
\text { ity }\end{array}$ \\
\hline Workforce & Yes & No & No & Yes & $\begin{array}{l}\text { Temporary } \\
\text { competitive } \\
\text { advantage }\end{array}$ \\
\hline $\begin{array}{l}\text { Standard manual } \\
\text { book Design }\end{array}$ & Yes & No & No & No & $\begin{array}{l}\text { Competitive Par- } \\
\text { ity }\end{array}$ \\
\hline $\begin{array}{l}\text { Equipment for survey } \\
\text { and design }\end{array}$ & Yes & No & No & No & $\begin{array}{l}\text { Competitive Par- } \\
\text { ity }\end{array}$ \\
\hline Certification architect & Yes & No & No & No & $\begin{array}{l}\text { Competitive Par- } \\
\text { ity }\end{array}$ \\
\hline \multicolumn{6}{|l|}{ Intangible } \\
\hline $\begin{array}{l}\text { Reputation and expe- } \\
\text { rience company }\end{array}$ & Yes & No & No & No & $\begin{array}{l}\text { Competitive Par- } \\
\text { ity }\end{array}$ \\
\hline Company culture & Yes & No & No & No & $\begin{array}{l}\text { Competitive Par- } \\
\text { ity }\end{array}$ \\
\hline
\end{tabular}


Volume 3 Issue 10 (December 2021) PP. 49-68 DOI 10.35631/AIJBES.310005

\begin{tabular}{|l|c|c|c|c|c|}
\hline $\begin{array}{l}\text { Good relationship } \\
\text { and networking with } \\
\text { business partners. }\end{array}$ & Yes & No & No & Yes & $\begin{array}{c}\text { Temporary } \\
\text { competitive } \\
\text { advantage }\end{array}$ \\
\hline $\begin{array}{l}\text { Competencies and } \\
\text { professional level of } \\
\text { the workforce. }\end{array}$ & Yes & No & No & No & $\begin{array}{c}\text { Competitive Par- } \\
\text { ity }\end{array}$ \\
\hline $\begin{array}{l}\text { Creativity and inno- } \\
\text { vation of architects. }\end{array}$ & Yes & No & No & No & $\begin{array}{c}\text { Competitive Par- } \\
\text { ity }\end{array}$ \\
\hline $\begin{array}{l}\text { Leadership capability } \\
\text { Management }\end{array}$ & Yes & No & No & No & $\begin{array}{c}\text { Competitive Par- } \\
\text { ity }\end{array}$ \\
\hline knowledge & Yes & No & No & No & $\begin{array}{c}\text { Competitive Par- } \\
\text { ity }\end{array}$ \\
\hline
\end{tabular}

Source: Author Analysis, 2020

VRIO framework is the tool used to analyze a firm's internal resources and capabilities to investigate whether they are a source of sustained competitive advantage. The result of the VRIO framework is obtained from the interview with the internal organization. Based on the VRIO analysis, all the resources of Top House are still in the category of competitive parity and temporary competitive advantage. This means that the company requires the right strategy formulation to make resources and capabilities become a sustainable competitive advantage. This analysis will be explained further in the SWOT analysis section.

\section{Value Chain Analysis}

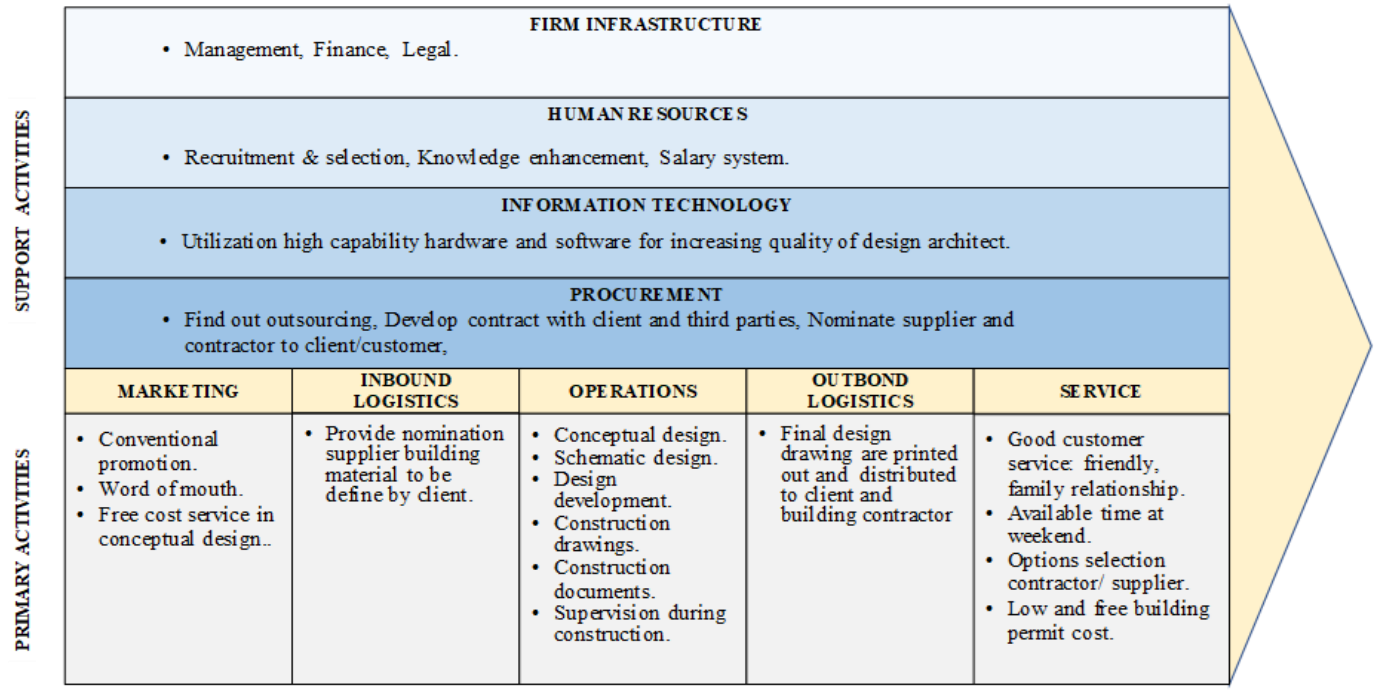

Figure 2. Top House Value Chain Analysis

Source: Author Analysis, 2020

Value chain Analysis refers to a framework for understanding how a business process value is created to provide a competitive advantage. The result of the value chain was obtained from the interview with the internal organization, business partnership, and client. Based on this analysis, it can be categorized as a strength or weakness as outlined below. 
Strength: Firm Infrastructure

- The market price of the small architecture firm is approximately $4 \%$ of the total cost of building construction. Due to the high competition in the market, Top House offers consultation prices below the average price to attract more customers and increase its supply.

Weaknesses: Marketing, Operations, Firm Infrastructure, Human Resources

- The company only implements the marketing by word of mouth (WOM) and offers free service in the conceptual design. This strategy is ineffective due to client dissatisfaction. Further, it does not recommend clients to others thus, this condition causes a decline in their number. Therefore, the company should evaluate WOM strategy and perform other marketing activities to increase clients.

- After conducting client interviews, this firm was unavailable during operation process service, including inadequate response complaints and correct feedback, slow addressing client's concerns, lack of commitment, improvement of progress report consistently, incompetencies as planner and supervisor, and improper communication and coordination during the construction process.

- The company has not developed and implemented the human resource management system properly. There are many HR concerns like the lack of soft and hard skills, high employee turnover rate ( $80 \%$ per year), and lack of people development system.

- The company has an inadequate management system. They have managed business conventionally only based on one SOP design, and there is no written company policy.

- The revenue and net profit significantly decreased by around 20\% from 2017 to 2019 and $75 \%$ from 2016 to 2019, respectively. The profit decreased significantly are caused the revenue decreased and company expenditure increase significantly as affected the increasing installment payment of company debt and increasing the operational cost. In addition, cashflow still positive although the amount decreased. 
The Existing Business Model Canvas

THE BUSINESS MODEL CANVAS

\begin{tabular}{|c|c|c|c|c|c|}
\hline $\begin{array}{c}\text { KEY } \\
\text { PARTNERS }\end{array}$ & $\begin{array}{c}\text { KEY } \\
\text { ACTIVIIIES } \\
\end{array}$ & \multicolumn{2}{|c|}{$\begin{array}{c}\text { VALUE } \\
\text { PROPOSIIIONS } \\
\end{array}$} & $\begin{array}{c}\text { CUSTONER } \\
\text { RELATIONSHIPS }\end{array}$ & $\begin{array}{l}\text { CUSTOMER } \\
\text { SEGMENTS }\end{array}$ \\
\hline \multirow[t]{3}{*}{$\begin{array}{l}\text { - Quantity surveyor. } \\
\text { Dodie freelancer } \\
\text { - Civil engineering } \\
\text { - 3D animator. Ichan } \\
\text { Freelancer, Icha } \\
\text { Freelancer } \\
\text { - Interior Designer: } \\
\text { Inori, Green Wood } \\
\text { Furniture. } \\
\text { - Building } \\
\text { Contractor. } \\
\text { Bewillal CV, } \\
\text { Marstand CV } \\
\text { - Building Material } \\
\text { Supplier. }\end{array}$} & $\begin{array}{l}\text { - Architectural de sign } \\
\text { development } \\
\text { - Develop budget } \\
\text { estimation for } \\
\text { construction } \\
\text { - Presentation building } \\
\text { design to client } \\
\text { - Nominate supplier for } \\
\text { matenial selection and } \\
\text { contractor. } \\
\text { - Prepare document } \\
\text { construction. } \\
\text { - Supervision during } \\
\text { construction. } \\
\text { - Office administration }\end{array}$ & \multirow{2}{*}{\multicolumn{2}{|c|}{$\begin{array}{l}\text { - Competitive consultant } \\
\text { fees. } \\
\text { - Modem tropical building } \\
\text { design concept that less } \\
\text { maintenance and lower } \\
\text { electric consumption. }\end{array}$}} & $\begin{array}{l}\text { - Personal asisstance } \\
\text { - Online communication } \\
\text { through Email, } \\
\text { Telephone, and } \\
\text { WhatsApp }\end{array}$ & \multirow[t]{3}{*}{$\begin{array}{l}\text { - Upper class } \\
\text { people } \\
\text { - B2C Model } \\
\text { - Low and } \\
\text { Medium Rise } \\
\text { Buiding focus } \\
\text { on personal } \\
\text { resdence, office } \\
\text { and shophouse. } \\
\text { - Businessman, } \\
\text { Professional, } \\
\text { Exective (age } \\
\text { 25-65 years old }\end{array}$} \\
\hline & \begin{tabular}{l}
\multicolumn{1}{c}{ KEY } \\
RESOURCES \\
- Human resources \\
- Tools Design Hardware \& \\
software \\
Office failties and \\
Equipment for design on \\
a asets. \\
operational vehicle \\
Business parthers \\
- Internet
\end{tabular} & & & $\begin{aligned} \text { CHANNELS } \\
: \text { Word of mouth } \\
: \text { Direct selling } \\
\text { Telephone service }\end{aligned}$ & \\
\hline & \multicolumn{2}{|l|}{ COST STRUCTURE } & \multicolumn{2}{|c|}{ REVENUE STREAMS } & \\
\hline \multicolumn{3}{|c|}{ 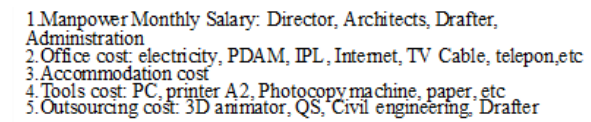 } & \multicolumn{3}{|c|}{$\begin{array}{l}\text { 1. Architectural design services fee: } 2 \mathrm{D} \text { Drawings, } 3 \mathrm{D} \text { modelling, } \\
\text { Rendering, Animation + Supervision fee. } \\
\text { 2. Building permit fee }\end{array}$} \\
\hline
\end{tabular}

Figure 3. Top House Existing Business Model Canvas

Source: Author Analysis, 2020

It is a framework for describing a business model through nine building blocks, namely Customer segments, Value propositions, Channels, Cost structure, Customer relationships, Revenue streams, Key resources, activities, and Partnerships. The business model canvas data was collected through interviewing the internal organization. The value propositions was categorized as a strength in the company. This is because of its strong positive effect on delivery value from the company to a client. It includes modern tropical architecture style, which gives a strong character to the building and remains the most popular. Further, the building concept with less maintenance and lower electric consumption provides better value in design. All the values propositions are the competitive advantage of Top House. This analysis will be explained further in the SWOT analysis section. 


\section{SWOT Analysis}

\section{Table 4. Top House SWOT}

\begin{tabular}{|c|c|}
\hline STRENGTH (Internal) & WEAKNESS (Internal) \\
\hline $\begin{array}{l}\text { - Competitive consultant fee. (BMC, } \\
\text { Value Chain Analysis) } \\
\text { - Modern tropical building design } \\
\text { concept that less maintenance and } \\
\text { lower electric consumption. (BMC) }\end{array}$ & $\begin{array}{l}\text { - Less marketing activities. (BMC, Value } \\
\text { Chain Analysis) } \\
\text { - Lack of service during operation process. } \\
\text { (Value Chain Analysis) } \\
\text { - Lack of human resources capability. } \\
\text { (Value Chain Analysis, VRIO) } \\
\text { - Inadequate of management system. } \\
\text { (Value Chain Analysis) } \\
\text { - Increasing company expenditure. (Value } \\
\text { Chain Analysis) }\end{array}$ \\
\hline OPPORTUNITY (External) & THREAT (External) \\
\hline $\begin{array}{l}\text { - Information technology development. } \\
\text { (PESTEL) } \\
\text { - Building design concept to include } \\
\text { green architecture requierement. } \\
\text { (PESTEL) } \\
\text { - Increasing demand on landed house } \\
\text { building. (PESTEL) }\end{array}$ & $\begin{array}{l}\text { - Tight competition among small } \\
\text { architecture firm.(PESTEL, Five Porter's } \\
\text { Force, Competitor Analysis) } \\
\text { - Price war among competitor. (Five } \\
\text { Porter's Force, Competitor Analysis) }\end{array}$ \\
\hline
\end{tabular}

Source: Author Analysis, 2020

A SWOT Analysis evaluates the internal strengths, internal weaknesses, external opportunities, and external threats in an organization's environment. The strengths are obtained from the value chain analysis and the business model canvas, whereas the weaknesses are obtained from the value chain analysis, business model canvas, and VRIO. The opportunities are obtained from the PESTEL, while threats are obtained from the PESTEL, five-porter's force and the competitor analysis. The variable on the SWOT table will be used in the IE matrix, including EFE, IFE, and Tows Matrix.

\section{External Factor Evaluatıon (EFE) Matrix}

Table 5: EFE Score

\begin{tabular}{|c|c|c|c|c|c|c|c|c|c|c|c|}
\hline \multirow[t]{2}{*}{ No } & \multirow[t]{2}{*}{ Opportunity } & \multirow[t]{2}{*}{ Weight } & \multicolumn{5}{|c|}{ Rating } & \multirow{2}{*}{$\begin{array}{l}\text { Average } \\
\text { Rating }\end{array}$} & \multirow[t]{2}{*}{ Stdev } & \multirow[t]{2}{*}{$\mathrm{CV}$} & \multirow[t]{2}{*}{ Score } \\
\hline & & & 1 & 2 & 3 & 4 & 5 & & & & \\
\hline 1 & Information technology development & 0.227 & 3 & 3 & 2 & 3 & 3 & 2.8 & 0.447214 & $16 \%$ & 0.635 \\
\hline 2 & Building design green architecture & 0.187 & 2 & 2 & 2 & 2 & 3 & 2.2 & 0.447214 & $20 \%$ & 0.411 \\
\hline 3 & $\begin{array}{l}\text { Increasing demand on landed house } \\
\text { building }\end{array}$ & 0.200 & 2 & 2 & 2 & 2 & 2 & 2 & 0 & $0 \%$ & 0.400 \\
\hline No & Threat & & & & & & & & & & \\
\hline 1 & $\begin{array}{l}\text { Tight competition among small } \\
\text { architecture firm }\end{array}$ & 0.200 & 1 & 1 & 1 & 1 & 1 & 1 & 0 & $0 \%$ & 0.200 \\
\hline 2 & price awar among competitor & 0.187 & 4 & 4 & 4 & 4 & 4 & 4 & 0 & $0 \%$ & 0.747 \\
\hline & Total & 1.0 & & & & & & & & & 2.392 \\
\hline
\end{tabular}

Source: Author Analysis, 2020

External Factor Evaluation (EFE) Matrix is used to examine company's external environment. This analysis is performed by focusing on group discussion among five architects within the Copyright $\odot$ GLOBAL ACADEMIC EXCELLENCE (M) SDN BHD - All rights reserved 
Volume 3 Issue 10 (December 2021) PP. 49-68 DOI 10.35631/AIJBES.310005

organization where each architect gave a weighting and rating for each key external factor. From the table above, it can be seen that the result of the EFE matrix is 2.392 which represents that the company has a medium internal position. This EFE matrix will be explained further in the IE matrix position section.

\section{Internal Factor Evaluatıon (IFE) Matrix}

Table 6: IFE Score

\begin{tabular}{|c|c|c|c|c|c|c|c|c|c|c|c|}
\hline \multirow[t]{2}{*}{ No } & \multirow[t]{2}{*}{ Strength } & \multirow[t]{2}{*}{ Weight } & \multicolumn{5}{|c|}{ Rating } & \multirow{2}{*}{\begin{tabular}{|c|} 
Aver age \\
Rating
\end{tabular}} & \multirow[t]{2}{*}{ Stdev } & \multirow[t]{2}{*}{ CV } & \multirow[t]{2}{*}{ Score } \\
\hline & & & 1 & 2 & 3 & 4 & 5 & & & & \\
\hline 1 & Competitive consultant fee & 0.162 & 4 & 4 & 3 & 3 & 3 & 3.4 & 0.547723 & $16 \%$ & 0.550 \\
\hline 2 & $\begin{array}{l}\text { Modern tropical building design that less } \\
\text { maintenance and low electric } \\
\text { consumption }\end{array}$ & 0.162 & 3 & 3 & 3 & 3 & 3 & 3 & 0 & $0 \%$ & 0.486 \\
\hline No & Weakness & & & & & & & & & & \\
\hline 1 & Less marketing activities & 0.171 & 2 & 2 & 2 & 3 & 2 & 2.2 & 0.447214 & $20 \%$ & 0.377 \\
\hline 2 & Less service during opration process & 0.190 & 2 & 2 & 2 & 2 & 2 & 2 & 0 & $0 \%$ & 0.381 \\
\hline 3 & Lack of human resources capabilities & 0.171 & 1 & 1 & 1 & 1 & 1 & 1 & 0 & $0 \%$ & 0.171 \\
\hline 4 & Inadequate manajement system & 0.143 & 2 & 2 & 2 & 2 & 3 & 2.2 & 0.447214 & $20 \%$ & 0.314 \\
\hline 5 & Increasing company expenditure. & 0.190 & 2 & 2 & 2 & 2 & 2 & 2 & 0 & $0 \%$ & 0.381 \\
\hline & Total & 1.0 & & & & & & & & & 2.280 \\
\hline
\end{tabular}

Source: Author Analysis, 2020

Internal Factor Evaluation (IFE) Matrix is used to examine company's internal environment. This analysis is done by conducting a group discussion among five architects within the organization where each architect gave a weighting and rating for each key internal factor. From the table above, it can be seen that the result of the IFE matrix is 2.280 which represents that the company has an average internal position. This IFE matrix will be explained further in the IE matrix position section.

\section{IE Matrix Position - Company Level strategy}

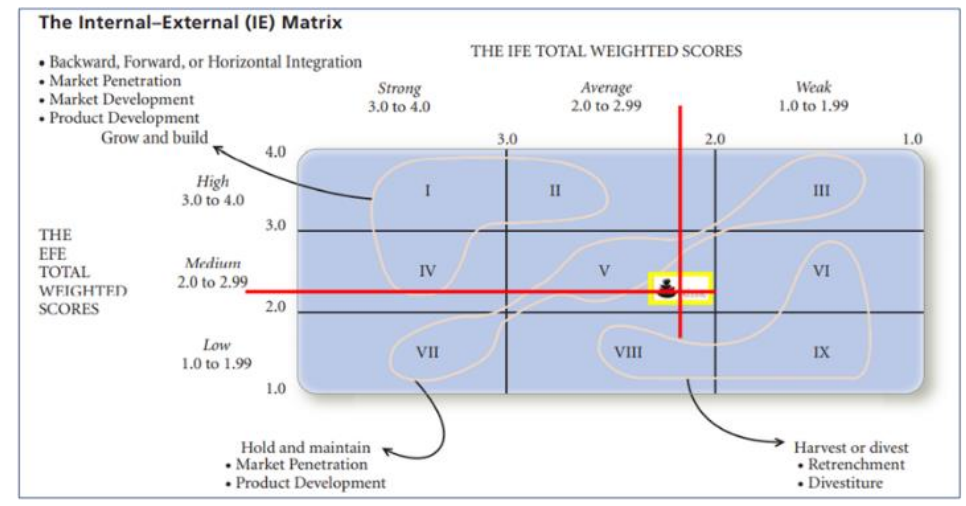

Figure 4. Top House IE Matrix

Source: Author Analysis, 2020

The External Factor Evaluation (EFE) scoring as the $\mathrm{x}$-axis is 2.392, while Internal Factor Evaluation (IFE) as the y-axis is 2.280. Consequently, the current company position is classified in cluster $\mathrm{v}$ (five). This means Top House should implement hold and maintain a business strategy consisting of market penetration and product development. To achieve the right strategy, this study implement pros and cons as alternative strategies as follows: 
Volume 3 Issue 10 (December 2021) PP. 49-68

Table 7: Pros \& Cons of Alternative Strategies

DOI 10.35631/AIJBES.310005

\begin{tabular}{|c|c|c|c|}
\hline No & Strategy & Pros & Cons \\
\hline 1 & $\begin{array}{l}\text { Market Pen- } \\
\text { etration }\end{array}$ & $\begin{array}{l}\text { Top House has a competitive price } \\
\text { over opponents. } \\
\text { - Market landed housing is growing. } \\
\text { - Top House has less activity market- } \\
\text { ing. } \\
\text { The market share of Top House is } \\
\text { lower than a competitor. } \\
\text { This firm is located in the right mar- } \\
\text { ketplace and close to a large demand } \\
\text { market. } \\
\text { The competitor has done intensive } \\
\text { marketing. }\end{array}$ & $\begin{array}{l}\text { - The company's repu- } \\
\text { tation is not strong } \\
\text { enough. } \\
\text { - It has no experienced } \\
\text { marketer yet. } \\
\text { - The capability and ca- } \\
\text { pacity of the organi- } \\
\text { zation is still weak. } \\
\text { The company has not } \\
\text { availed a proper mar- } \\
\text { keting system. }\end{array}$ \\
\hline 2 & $\begin{array}{l}\text { Product De- } \\
\text { velopment }\end{array}$ & $\begin{array}{l}\text { The modern tropical design building } \\
\text { concept matches with green architec- } \\
\text { ture requirements. } \\
\text { - Availability of technology for sup- } \\
\text { porting product development. } \\
\text { - Increasing trend of green environ- } \\
\text { ment requirements related to global } \\
\text { warming issue. } \\
\text { - Tight competition among small ar- } \\
\text { chitecture firms. } \\
\text { - The product still lacks service and } \\
\text { needs to be improved. } \\
\text { - The price war among competitors. } \\
\text { High forces from new entrants and } \\
\text { rivalry among existing competitors } \\
\text { of the small architecture firm. } \\
\text { Creates different values of the prod- } \\
\text { uct regarding competition in the mar- } \\
\text { ket. }\end{array}$ & $\begin{array}{l}\text { - It increased the ex- } \\
\text { penditure cost for } \\
\text { product development. } \\
\text { - Lack of competent } \\
\text { people in the organi- } \\
\text { zation. }\end{array}$ \\
\hline
\end{tabular}

Source: Author Analysis, 2020

The pros and cons are used to answer a strategic question. This analysis is obtained from the focus group discussion. The list all of pros column reveal the reasons why choose this option strategy, while the list of cons columns reveal the reason why not choosing this option strategy. Based on this analysis, the company should implement a product development strategy due to the value of Top House, which needs to be improved. Further, it adds a value proposition for its strength, thus giving it a competitive advantage and increasing the market share. 


\begin{tabular}{|c|c|c|}
\hline & $\begin{array}{l}\text { Strength: } \\
\text { 1. Competitive consultant fee. } \\
\text { 2. Modem tropical concept that less } \\
\text { maintenance and lower electricity } \\
\text { consumption. }\end{array}$ & $\begin{array}{l}\text { Weakness: } \\
\text { 1. Less marketing activities. } \\
\text { 2. Lack of service during op eration process. } \\
\text { 3. Lack of human resources capability. } \\
\text { 4. Inadequate of management system } \\
\text { 5. Increasing company expenditure }\end{array}$ \\
\hline \multirow{2}{*}{$\begin{array}{l}\text { Opportunity: } \\
\text { 1. Information technology } \\
\text { development. } \\
\text { 2. Building design concept to } \\
\text { include green architecture } \\
\text { requirement. } \\
\text { 3. Increasing demand on } \\
\text { landed house building. }\end{array}$} & SO Strategies & WO Strategies \\
\hline & $\begin{array}{l}\text { - Optimize product value to meet green } \\
\text { architecture requierement. [S2, O2, O3] }\end{array}$ & $\begin{array}{l}\text { - Increase Marketing activity by multichannel } \\
\text { marketing method. [W1, O1, O3] } \\
\text { - Improve supporting IT facilities to enhance } \\
\text { effectiveness of business process. [W4, O1, } \\
\text { O3] } \\
\text { - Utilize BIM technology to enhance } \\
\text { productivity of process design. [W2, O1, } \\
\text { O3] } \\
\text { - Enhance organization capability by } \\
\text { developing appropriate HRD system [W2, } \\
\text { W3, O3] } \\
\text { - Develop management system as framework } \\
\text { for effectiveness business process and } \\
\text { procedures. [W2, W4, O3] }\end{array}$ \\
\hline \multirow{2}{*}{$\begin{array}{l}\text { Threat: } \\
\text { 1. Tight competition among } \\
\text { small architecture firm } \\
\text { 2. Price war among competitor. }\end{array}$} & ST Strategies & WT Strategies \\
\hline & $\begin{array}{l}\text { - Enhance company branding. [S2, T1,T2] } \\
\text { - Maintain competitiveness of the price in the } \\
\text { market. [S1, T1,T2] }\end{array}$ & $\begin{array}{l}\text { - Enhance loyality of customer with } \\
\text { implement customer relationship } \\
\text { management system [W1, T1 ] } \\
\text { - Update the business posisitioning in the } \\
\text { market regulary. [W1, W2, T1] } \\
\text { - Retructuring company expenditure for } \\
\text { reducing spending cost. [W5, T1, T2 ] }\end{array}$ \\
\hline
\end{tabular}

Figure 5. Top House TOWS Matrix

Source: Author Analysis, 2020

The TOWS Matrix is derived from the SWOT Analysis model that aimed to develope strategic options from an external-internal analysis. The strategies are centered on exploiting opportunities, minimizing threats, overcoming weaknesses, and capitalizing on strengths. These strategies are determined by the authors due to it is the best and most profitable strategy choice that are in line with the company's vision and mission and company level strategy. From the table above, there are 11 functional strategies applied in the marketing, human resources, operations, and finance area. The results of the TOWS matrix are depicted in the following section.

Table 8: Top House TOWS Result

\section{Marketing Strategy}

- Enhance company branding.

- Maintain competitiveness of the price in the market by monitoring the price policy in the market and updating existing pricing methodology.

- Increase marketing activity by multichannel method, consisting of: 
Volume 3 Issue 10 (December 2021) PP. 49-68 DOI 10.35631/AIJBES.310005

○ Offline marketing: proactive participate in Community/club, attend the architectural exhibition, seminar, and architectural design contest.

○ Online marketing: social media marketing, search engine optimization through an excellent website.

- Enhance loyalty through implementing a customer relationship management system.

- Update the business positioning regularly by conducting competitor analysis and developing customer satisfaction questionnaires after the project completion.

\section{Human Resource Strategy}

- Enhance organization capability by developing appropriate HRD system, consisting of: ○ Establishing a recruitment system.

- Performance appraisal system consisting of job target, performance (hard and soft skill), and behavior.

- People development system, comprising of the regular internal job training program, visiting an architectural exhibition, joining seminar related to architecture, implementing coaching and mentoring program, job enlargement and enrichment for potential talented employee, job training for an incompetent employee, activate and participate in IAI organization activities.

- A good remuneration system, consisting of salary and allowances, benefit, reward, and recognition.

- Employee relationship plan, conducting events together between superior and subordinate or every employee regularly and proposing good workplace improvements (physic).

\section{Operational Strategy}

- Optimize product value to meet green architecture requirements.

- Improve supporting IT facilities to enhance the effectiveness of the business process.

- Utilize BIM technology to promote the productivity of process design.

- Develop management system as a framework for effective business process and procedures, consisting of:

o Develop and establish company policy clearly as a reference to run the business appropriately.

- Review, update and improve the existing management system based on a plan, do, check, action (PDCA) as a framework for business process and procedure.

- Develop and create a standard operating procedure (SOP) for every area/section as a guideline for each employee's work.

\section{Financial Strategy}

- Restructuring company expenditure for reducing spending cost, consisting of:

- Reorganizing company debt (Extend tenor of the company debt to reduce annual installment costs and early payment to reduce the number of debts).

- Remove expenditure costs not related to core business.

- Reduce workforce for drafter and animator cost as affected utilization of BIM technology.

- Evaluate the effectiveness of spending and cost for utilizing additional information technology to prevent a significant impact on financial performance.

Source: Author Analysis, 2020 
THE NEW BUSINESS MODEL CANVAS

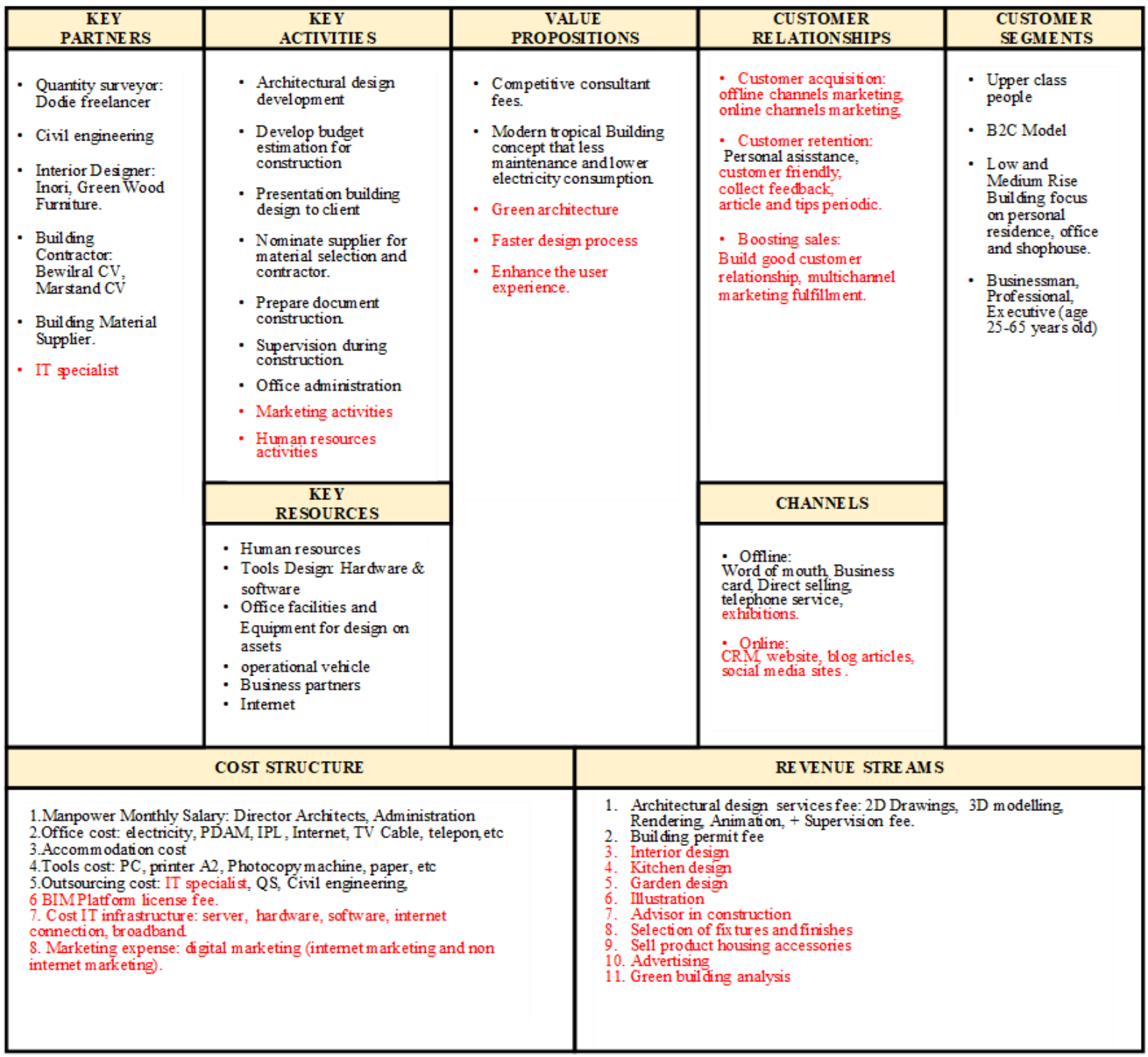

Figure 6. Top House New Business Model Canvas

Source: Author Analysis, 2020

This is a guideline for the company to implement a new business model which in line with the company strategy and functional strategy. Based on this, the changes to the seven elements of this model canvas, namely key partners, key activities, value propositions, customer relationships, channels, cost structure, and revenue streams.

There are additional two key activities in business model canvas, specifically marketing and human resources for maximize working process outputs and deliver architect products. Also, the company adds the value proposition to give a better value to the customer. This promotes his satisfaction by enhancing the user experience, providing better service, and positively impacting the environment. Moreover, Top House company optimizes customer relationships 
Volume 3 Issue 10 (December 2021) PP. 49-68 DOI 10.35631/AIJBES.310005

with online and offline marketing strategies to create new clients and maintain them. Besides that, this firm adds revenue streams to increase the company's income and seek the maximum possible profit. These changes lead to additions to the cost structure and key partners. Meanwhile, the customer segment of Top House remained constant before because it is generally limited for the potential upper-class opportunity, a big market for an architecture firm for people who live in the Jabodetabek area, and in this regard the green architecture building concept matches with the existing ones of Top House.

\section{Conclusion}

Top House has faced a decline in revenue and profit in three consecutive years due to the dissatisfaction with the product quality and inadequate marketing activities, which lead to an inability of the firm to get new clients. This condition occurs because the unavailability of a comprehensive management system and poor company management. Consequently, the company is challenged when competing with others in the intense business competition situation. Regarding the increase in revenue and profit, this firm should develop business strategies and action plans to improve its performance.

After analyzing, Top House should implement a hold and maintain strategy with product development strategy. This strategy is performed by improving the existing product quality, consisting of green architectural requirements in the design concept, and utilizing BIM technology. Further, it makes the Top House product value different and better than competitors. In order to realize this, the company should develop a functional strategy based on the TOWS matrix to fix the current internal weakness to make the business more effective and efficient. In addition, the company should upgrade the business model canvas. These methods are purposively in increasing the revenue and net profit, improving business performance, and the ability to compete in the market. In this way, the business can grow and be sustained for a long period.

\section{References}

Adom, D., Hussein, E. K., \& Joe, A.--agyem. (2018). Theoretical and Conceptual Framework: Mandatory Ingredients of Quality Research. International Journal of Scientific Research, 7, 438-441.

andi.link, (2020). Hootsuite (We are Social): Indonesian Digital Report 2020. Available from https://andi.link/hootsuite-we-are-social-indonesian-digital-report-2020/ [Accessed on 11 September 2020].

archify.com., (2020). Hasil Survei: Reaksi Biro Arsitektur dan Desain terhadap Situasi Covid19. Available from ttps://www.archify.com/id/archifynow/hasil-survei-reaksi-biro-arsitektur-dan-desain-terhadap-situasi-covid-19 [Accessed on 3 December 2020].

autodesk.com., (2020). Design and Build with BIM. Available from https://www.autodesk.com/solutions/bim [Accessed on 12 September 2020].

bps.go.id, (2019). Consumption Expenditure of Population of Indonesia by Province [Susenas]. Availablefromfile:///D:/3.\%20thesis/source\%20bab\%202/pestel/3.\%20social/consumption/Pengeluaran\%20untuk\%20Kosumsi\%20Penduduk\%20Indonesia\%20per\%20Provinsi,\%20September\%202019.pdf [Accessed on 10 September 2020].

Cendana, 2015, Gaya Arsitektur di Indonesia, cendana id, Available from https://www.cendana.id/index.php/2015/06/29/gaya-arsitektur/ [Accessed on 10 September 2020]. 
Volume 3 Issue 10 (December 2021) PP. 49-68 DOI 10.35631/AIJBES.310005

Charyk, C. (2017). The Pros and Cons of Pros-and-Cons Lists. Available from https://hbr.org/2017/01/the-pros-and-cons-of-pros-and-cons-lists. [Accessed on 10 September 2020].

Creswell, J. W. (2018). Research Design: Qualitative, Quantitative, and Mixed Methods Approaches. (5th Ed.). New York: SAGE.

data.worldbank.org. (2020). GDP, GDP Growth, GDP Per capita, GDP Per capita Growth. Available from https://data.worldbank.org/country/indonesia [Accessed on 9 September 2020].

David, Fred R. (2011). Strategic Management: Concepts and Cases (13th ed.). New Jersey: Prentice Hall.

dekoruma.com. (2020). 6 Prediksi Gambar Rumah yang Akan Tren di Tahun 2021. Available from https://www.dekoruma.com/artikel/113548/tren-gambar-rumah [Accessed on 8 September 2020].

Donal C. Hambrick \& James W. Fredrickson. (2001). Are you sure you have a strategy? Academy of Management Executive (Vol 15 no 4). New York: Academy of Management.

Douglas, M. (2015). Sources of data. Available from http://www.onlineetymologydictionary/data [Accessed on 13 September 2020].

Fauzian, R. (2019). Tangerang Membukukan Penjualan Properti Terbesar, medcom.id. Available from https://www.medcom.id/properti/news-properti/8Ky5e7EK-tangerang-membukukan-penjualan-properti-terbesar.

Hanegraaf, J. (2017). Architectural Technology. Available from https://www.johanhanegraaf.nl/speaking-virtual-reality/ [Accessed on 12 September 2020].

iaijakarta.org. (2020). Digital Transformation AGC in BIM. Available from https://www.iaijakarta.org/download?p=\%2FForum+BIM\%2FBIM+dan+FASADE [Accessed on 12 September 2020].

kemenperin.go.id, (2017). Empat Strategi Indonesia Masuk Revolusi Industri Keempat. Available from https://kemenperin.go.id/artikel/17565/Empat-Strategi-Indonesia-MasukRevolusi-Industri-Keempat [Accessed on 11 September 2020]

Kotler, P., \& Armstrong, G. (2018). Principles of Marketing. (7th ed.). United States: Pearson Education.

Kotler, P., \& Keller, K. L. (2016). Marketing Management. United States: Pearson Education.

Lusida, P.T. (2020). Penjualan Rumah dibawah Rp. 1,5 Miliar melonjak 83 persen, Available from https://properti.kompas.com/read/2020/10/15/162934521/penjualan-rumah-dibawah-rp-15-miliar-melonjak-83-persen [Accessed on 13 December 2020].

Mazaya, B. (2020). Tren Green Building. Available from https://news.detik.com/kolom/d5124110/tren-green-building [Accessed on 6 December 2020].

Mesly, O. (2015). Creating models in psychological research. Etats-Unis: Springer press.

ncdc.noaa.gov., (2019, June). Global Climate Report. Available from https://www.ncdc.noaa.gov/sotc/global/201906 [Accessed on 13 September 2020].

newdecortrends.com. (2020). New Architecture Trends for 2020 and 2021. Available from https://newdecortrends.com/new-architecture-trends-for-2020-and-2021/ [Accessed on 8 September 2020].

Oman. (2015). Competitor Analysis. Available from https://bbs.binus.ac.id/gbm/2017/06/07/competitor-analysis/

Osterwalder, A., \& Pigneur, Y. (2010). Business Model Generation: A Handbook for Visionaries, Game Changers, and Challengers. New York: Wiley.

Pawitro, U. (2011). Mengenal Dunia Arsitektur, Kegiatan Profesi Arsitek dan perancangan Arsitektur.

Available

from

https://www.academia. 
edu/4731688/MENGENAL_DUNIA_ARSITEKTUR_KEGIATAN_PROFESI_ARSITEK_DAN_PERANCANGAN_ARSITEKTUR [Accessed on 8 August 2020].

Rangkuti, F. (2008). Analisis Swot Teknik Membedah Kasus Bisnis Reorientasi Konsep Perencanaan Strategis Untuk Menghadapi Abad 21. Jakarta : Gramedia Pustaka Utama.

Rothaermel, F. T. (2017). Strategic Management (3rd ed.). New York: McGraw-Hill Education.

theconstructor.org. (2014). Green Building Concept, Available from https://theconstructor.org/building/what-makes-a-building-green-green-building-concept/7327/ [Accessed on 13 September 2020].

tradingeconomics.com, (2020). Indonesia Interest. Available from https://tradingeconomics.com/indonesia/interestrate\#: :text=Looking\%20forward\%2C\%20we\%20estimate $\% 20$ Interest,according\%20to\%20our\%20econometric\%20models [Accessed on 9 September 2020].

University of Utah. (2019). Understanding Quantitative vs. Qualitative Research. Available from https://flexmr.medium.com/understanding-quantitative-vs-qualitative-research8f7cbf748765\#: :text=Qualitative\%20research\%20is\%20defined\%20by,'what')\%2C\%20qualitative\%20research.

Wheelen, Thomas L., \& Hunger, J. D. (2012). Strategic Management and Business Policy: Toward Global Sustainability (13th ed.). New Jersey: Prentice Hall.

worldometers.info, (2020). Indonesia Population. Available from https://www.worldometers.info/world-population/indonesia-population/ [Accessed on 10 September 2020].

Yeang. (2000). Building Material and Environmental Impact. Available from https://www.slideshare.net/adi5686/building-materials-and-environmental-impact. [Accessed on 13 September 2020]. 